\title{
Emerging Viral Diseases of Tomato Crops
}

\author{
Inge M. Hanssen, ${ }^{1}$ Moshe Lapidot, ${ }^{2}$ and Bart P. H. J. Thomma ${ }^{3}$ \\ ${ }^{1}$ Scientia Terrae Research Institute, Fortsesteenweg 30A, 2860 Sint-Katelijne-Waver, Belgium; ${ }^{2}$ Department of Vegetable \\ Research, Institute of Plant Sciences, Agricultural Research Organization, Volcani Center, P.O. Box 6, Bet Dagan 50-250, \\ Israel; ' ${ }^{3}$ Laboratory of Phytopathology, Wageningen University, Droevendaalsesteeg 1, 6708 PB Wageningen, The Netherlands
}

Submitted 7 December 2009. Accepted 15 January 2010.

\begin{abstract}
Viral diseases are an important limiting factor in many crop production systems. Because antiviral products are not available, control strategies rely on genetic resistance or hygienic measures to prevent viral diseases, or on eradication of diseased crops to control such diseases. Increasing international travel and trade of plant materials enhances the risk of introducing new viruses and their vectors into production systems. In addition, changing climate conditions can contribute to a successful spread of newly introduced viruses or their vectors and establishment of these organisms in areas that were previously unfavorable. Tomato is economically the most important vegetable crop worldwide and many viruses infecting tomato have been described, while new viral diseases keep emerging. Pepino mosaic virus is a rapidly emerging virus which has established itself as one of the most important viral diseases in tomato production worldwide over recent years. Begomovirus species and other whitefly-transmitted viruses are invading into new areas, and several recently described new viruses such as Tomato torrado virus and new Tospovirus species are rapidly spreading over large geographic areas. In this article, emerging viruses of tomato crops are discussed.
\end{abstract}

Despite tremendous efforts in human, animal, and plant health management, viral diseases remain notoriously difficult to control or eradicate. Moreover, currently used control strategies are compromised by the continuous emergence of new strains of existing viruses or of completely new viruses. Owing to their large population size and short generation time, viruses have a great potential to quickly evolve and adapt under natural selection pressure. The high incidence of mutation, recombination, and reassortment in viral genomes enhances the generation of new variants that, when the mutation results in a biological advantage, quickly spread throughout the viral population (Moya et al. 2004). In particular, RNA virus quasispecies, composed of large mutant swarms that contain major and minor mutations in their genome sequences, are highly effective in adapting to varying selection pressures because the pool of variants in the quasispecies "cloud" is a rich source of variation which can contain successful variants (Domingo 2000).

There are several definitions of emerging viruses. The world health organization (WHO) defines an emerging virus as "one that has appeared in a population for the first time, or that may have existed previously but is rapidly increasing in incidence

Corresponding author: B. P. H. J. Thomma; Telephone: 0031-317-484536; Fax: 0031-317-483412; E-mail: bart.thomma@wur.nl or geographic range." Others consider an emerging virus to be a virus that has recently changed or appeared to occupy and spread within a new niche (Rojas and Gilbertson 2008). Emerging viruses can be newly described viruses that were previously unknown. However, more frequently, emerging viruses are known viruses with an increased incidence in a certain niche due to changes in the environment, the vector, the host, or in the viral genome.

Virtually no antiviral products are available for plant disease management, leaving eradication or prevention through hygiene measures as the only immediate control strategies, although these practices have only met limited success. The best control strategy for a viral disease is the introduction of genetic resistance in the plant host. However, introgression of genetic resistance is time consuming and will, in most cases, become available only after the emerging virus has become well established.

Increasing international travel and trade of seed, seedlings, cuttings, and fruit enhances the risk of introducing new viruses and their vectors into production areas. Changing climate conditions can contribute to a more successful spread of the virus or its vector and establishment of these organisms in areas that were previously unfavorable, thus enhancing viral spread.

With a worldwide production of 130 million metric tons and a value of over 30 billion international dollars in 2007, tomato (Solanum lycopersicum) is by far the most important vegetable crop (source: Food and Agricultural Organization, United Nations). In terms of economical value, tomato constitutes $72 \%$ of the value of fresh vegetables produced worldwide. The number of described viral species that infect tomato crops amounts to 136 , whereas this number is notably lower for other vegetable crops with, for example, 49 viruses that infect pepper (Capsicum annuum), 53 that infect lettuce (Lactuca sativa), 46 that infect melon (Cucumis melo), 54 that infect potato $(S$. tuberosum), and 44 that infect eggplant ( $S$. melongena). Only for cucumber (C. sativis) have even more viral pathogens (153) been described (Brunt et al. 1996).

The high number of viral pathogens of tomato can partly be explained by the sensitivity of tomato to members of the genus Begomovirus, which harbors a large variety of species. In addition, years of intensive breeding for improved production may have narrowed the genetic basis for viral disease resistance in commercially grown tomato cultivars. Furthermore, the intensification of tomato production with large areas of protected monocropping under controlled climate conditions may generate the conditions for efficient spread and survival of viruses and their vectors, increasing the potential for emerging viruses to become endemic. Finally, although it may seem trivial, the economic importance of tomato also makes the study of patho- 
gens and pests affecting this crop a major topic in phytopathological research. Consequently, pathogens infecting tomato are generally well studied and characterized. Over recent years, several viral diseases, including Tomato yellow leaf curl virus (TYLCV; genus Begomovirus), Pepino mosaic virus (PepMV; genus Potexvirus), and Tomato torrado virus (ToTV) have emerged in greenhouse tomato crops and are presently impacting fresh-market tomato production in diverse geographic areas worldwide.

Considering the past 20 years, the most important emerging viral pathogens of tomato are discussed in this article, encompassing i) new viral species, ii) known viral pathogens of other crops that are emerging in tomato, and iii) tomato viruses with a rapidly increasing incidence. In addition, the reemergence of old viruses, that largely disappeared with the introduction of resistance, due to "specialty market"-driven culture of old tomato cultivars, is discussed.

\section{NEW VIRAL SPECIES THAT INFECT TOMATO}

Emerging species assembled in the novel Torradovirus genus.

In the past decade, two related viral species that are clearly distinct from previously described plant viruses simultaneously emerged in two distinct geographic regions, Spain and Mexico. Both viruses caused necrotic or burn-like disease symptoms in tomato crops. From 2001 onward, tomato plants with severe necrotic leaf symptoms were observed in protected tomato crops in the Murcia area in the southeast of Spain (Alfaro-Fernández et al. 2007b; Verbeek et al. 2007). Because of the burn-like appearance of affected leaves, the disease was locally referred to as "torrado" (roasted) disease. Initial disease symptoms consist of necrotic spots that are surrounded by a light green or yellow area at the base of the leaflets (Fig. 1A). In a later stage, leaves and fruit display severe necrosis and plants suffer an overall growth reduction resulting in serious economical damage (Verbeek et al. 2007). Diagnostics revealed the presence of PepMV in infected plants but, because the symptoms were atypical for PepMV, further studies were performed. In addition to the rod-shaped PepMV particles, isometric viral particles were observed by electron microscopy. Through inoculation of the indicator plants Physalis floridana and Nicotiana glutinosa that are not susceptible to PepMV, a virus with a bipartite positive-stranded (ss) RNA genome with three open reading frames (ORF) was purified. The virus shares virion characteristics and nucleotide sequence similarities with viruses from the genera Sequivirus, Waikavirus, Sadwavirus, and Cheravirus but phylogenetic analyses on two different genome regions revealed a separate taxonomic position. The name ToTV was proposed, and the species was proposed to belong to a novel genus (Verbeek et al. 2007) (Table 1).

Intriguingly, from 2003 onward, a highly similar disease (leaf, stem, and fruit necrosis) (Fig. 1E) was observed in Mexican tomato crops, locally known as "marchitez" (wilted) disease, which was initially thought to be caused by a $S w 5$ resis-
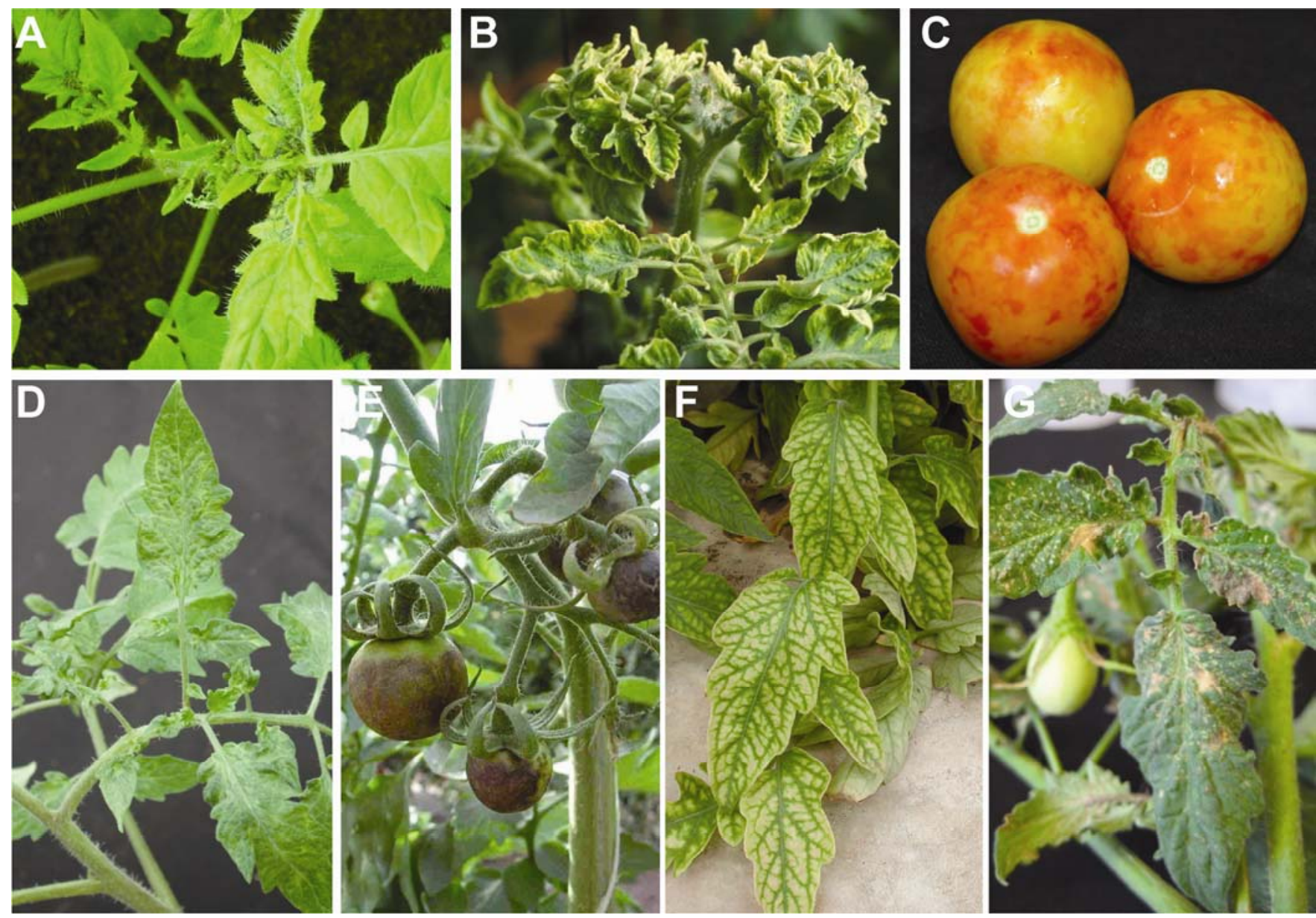

Fig. 1. Symptoms of emerging viruses in tomato plants. A, Necrotic spots at the leaflet base induced by Tomato torrado virus; B, leaf deformation, yellowing, and stunting induced by Tomato yellow leaf curl virus; $\mathbf{C}$, fruit marbling induced by Pepino mosaic virus; $\mathbf{D}$, chlorotic rings and line patterns on leaves induced by Pelargonium zonate spot virus; E, fruit necrosis induced by Tomato marchitez virus; F, interveinal leaf chlorosis induced by Tomato chlorosis virus; G, necrotic leaf spots induced by Tomato necrotic spot virus. Pictures E and G are kindly provided by P. Maris (De Ruiter Seeds, Bergschenhoek, The Netherlands) and R. Gilbertson (University of California, U.S.A.), respectively. 
tance-breaking strain of Tomato spotted wilt virus (TSWV; genus Tospovirus) (Turina et al. 2007), although this virus could not be detected in symptomatic plants. Electron microscopy revealed the presence of isometric viral particles in symptomatic plant material (Turina et al. 2007). Virus characterization and partial sequencing revealed that the virus was distinct from previously described viruses and the name 'Tomato apex necrosis virus" (ToANV) was proposed (Turina et al. 2007). In a parallel study on the same disease, analyses of morphology and genome structure showed that the virus causing marchitez disease was highly similar to ToTV (Verbeek et al. 2008). However, subsequent nucleotide sequence analyses revealed that the disease was caused by a new viral species that is clearly distinct from, albeit related to, ToTV, with nucleotide sequence identities of 85,63 , and $66 \%$ for the three ORF, and the name "Tomato marchitez virus" (ToMarV) was proposed (Verbeek et al. 2008) (Table 1). Phylogenetic analyses showed that ToTV, ToMarV, and ToANV are related and these new viruses are thought to belong to the same novel genus for which the name "Torradovirus" was proposed, with ToTV as the type species (Verbeek et al. 2008; Sanfaçon et al. 2009). ToMarV is considered a distinct species of the same genus and, because partial sequence comparison revealed $95 \%$ sequence homology, ToANV is considered to be a ToMarV isolate (Verbeek et al. 2008).

It was recently proposed to generate a new family within the order of Picornavirales, which currently contains mainly animal viruses that belong to the families Picornaviridae, Comoviridae, Dicistroviridae, Marnaviridae, and Sequiviridae and the unassigned plant virus genera Cheravirus and Sadwavirus (Le Gall et al. 2008). The name "Secoviridae" was proposed for the new family, which includes all plant viruses within the order and comprises the genera Comovirus, Fabavirus, Nepovirus, Sequivirus, Waikavirus, Cheravirus, Sadwavirus, and the new genus Torradovirus (Sanfaçon et al. 2009).

Rapidly after the initial characterization of ToTV, the virus was reported in greenhouse tomato crops in the Canary Islands (Alfaro-Fernández et al. 2007a), where the typical symptoms were already observed in 2003. Similarly, typical symptoms were observed in tomato crops in Poland already in 2003 and, based on nucleotide sequence comparisons ToTV, was identified afterward as the causal agent (Pospieszny et al. 2007). Although poor mechanical transmission was reported, efficient vectoring by the greenhouse whitefly Trialeurodes vaporiarium was demonstrated (Pospieszny et al. 2007). More recently, the whitefly Bemisia tabaci was shown to efficiently transmit the virus and other Solanaceous crops, including potato, eggplant, pepper, and tobacco ( $N$. tabacum), were re- ported as hosts (Amari et al. 2008). In addition, natural infection of weed hosts, possibly serving as alternative hosts in close proximity to Solanaceous crop production systems, was reported in Spain (Alfaro-Fernández et al. 2008b). In 2008, tomato plants exhibiting ToTV-like symptoms were observed in Panama and molecular analysis confirmed the presence of both ToTV and Cucumber mosaic virus (CMV). No difference in symptom expression was found between plants infected with both viruses or with ToTV alone (Herrera-Vasquez et al. 2009). Interestingly, out of 87 ToTV-infected samples with typical torrado disease symptoms that were collected between 2003 and 2006 in Spanish greenhouse tomato crops, 83 were simultaneously infected with PepMV (Alfaro-Fernández et al. 2007b). Recently, the virus was also reported in tomato crops in Hungary (Alfaro-Fernández et al. 2009) and in Australia (European Plant Protection Organization [EPPO]) (EPPO 2009), showing a rapid migration of ToTV over large geographical distances (Fig. 2), possibly in association with whiteflies. By contrast, thus far, ToMarV is only reported in Mexico, and information regarding ToMarV transmission is currently not available.

\section{New Crinivirus and Tospovirus spp.}

The Crinivirus spp. represent a group of viruses that emerged over the last decades in association with the worldwide emergence of whiteflies (Wisler et al. 1998a; Jones 2003; Wintermantel 2004). Whitefly populations (mainly the $B$. tabaci B biotype) have drastically increased worldwide since the 1970s, especially in tropical and subtropical areas (Wisler et al. 1998a). Even the greenhouse whitefly T. vaporariorum, for which epidemics have long been restricted to greenhouse crops, have been emerging in open-field vegetable production over the last 20 years, with large populations in summer crops and weed reservoirs (Wintermantel 2004). Increased insecticide resistance, global warming, changing of agricultural practices, and increasing global trade of plant materials have been suggested as factors enhancing whitefly emergence (Wintermantel 2004). Members of the genus Crinivirus within the family Closteroviridae have a bipartite ssRNA genome with the two segments separately encapsidated, and are transmitted by several species of Bemisia and Trialeurodes whiteflies in a semipersistent manner (Wintermantel 2004). In the last decade, two Crinivirus spp. emerged as a problem in tomato production, Tomato infectious chlorosis virus (TICV) and Tomato chlorosis virus $(\mathrm{ToCV})$

TICV was first identified in field-grown tomato crops in 1993 in California, with an estimated yield loss of 2 million U.S. dollars in that year alone (Duffus et al. 1996; Wisler et al.

Table 1. Emerging viruses of tomato crops reviewed in this article

\begin{tabular}{|c|c|c|c|c|}
\hline Family & Genus & Species & Geographical spread & Reference $^{a}$ \\
\hline \multirow[t]{2}{*}{$\overline{\text { Secoviridae }}$} & Torradovirus & Tomato torrado virus (ToTV) & $\begin{array}{l}\text { Spain, Canary Islands, Panama, Poland, } \\
\text { Hungary, Australia }\end{array}$ & Verbeek et al. 2007 \\
\hline & & Tomato marchitez virus (ToMarV) & Mexico & Verbeek et al. 2008 \\
\hline \multirow[t]{2}{*}{ Closteroviridae } & Crinivirus & Tomato infectious chlorosis virus (TICV) & $\begin{array}{l}\text { United States (California), Europe, } \\
\text { Middle East }\end{array}$ & Duffus et al. 1996 \\
\hline & & Tomato chlorosis virus (ToCV) & Europe (South), US, Middle-East & Wisler et al. 1998b \\
\hline \multirow[t]{2}{*}{ Bromoviridae } & Ilarvirus & Tomato necrotic spot virus (TNSV) & United States (Florida) & Batuman et al. 2009 \\
\hline & Anulavirus & Pelargonium zonate spot virus (PZSV) & $\begin{array}{l}\text { Israel, Europe (South), United States } \\
\text { (California) }\end{array}$ & Gallitelli 1982 \\
\hline \multirow[t]{3}{*}{ Bunyaviridae } & Tospovirus & Tomato yellow ring virus (TYRV) & Iran & Hassani-Mehraban et al. 2005 \\
\hline & & Capsicum chlorosis virus (CaCV) & Australia, China, Thailand, Taiwan & McMicheal at al. 2002 \\
\hline & & Tomato zonate spot virus (TZSV) & China & Dong et al. 2008 \\
\hline \multirow{2}{*}{$\begin{array}{l}\text { Flexiviridae } \\
\text { Geminiviridae }\end{array}$} & Potexvirus & Pepino mosaic virus (PepMV) & Worldwide except Middle-East & van der Vlugt et al. 2000 \\
\hline & Begomovirus & $\begin{array}{l}\text { Tomato yellow leaf curl virus (TYCLV) } \\
\text { and related species }\end{array}$ & Tropical and subtropical areas & Cohen and Harpaz 1964 \\
\hline
\end{tabular}

${ }^{\text {a }}$ First description for new viruses; first report in tomato for known viruses that recently emerged in tomato. 
1996). Tomato plants showing symptoms reminiscent of TICV infection have been reported in greenhouse tomato crops in Florida since 1989 (Wisler et al. 1998b). The disease was referred to as "yellow leaf disorder" and had been attributed to nutritional disorders or pesticide phytotoxicity, because initial analyses could not detect viral presence. However, transmission experiments revealed that this yellow leaf disorder was efficiently transmitted by whiteflies. A Crinivirus sp. that was distinct from TICV in terms of RNA sequence, vector specificity, and host range was isolated and named ToCV (Wisler et al. 1998b).

TICV is transmitted solely by the greenhouse whitefly $T$. $v a$ porariorum, whereas ToCV is transmitted by a number of whitefly species which include the greenhouse whitefly; the banded wing whitefly $T$. abutilonea; and the B. tabaci biotypes A, B, and Q (Navas-Castillo 2000; Wintermantal and Wisler 2006). The B. tabaci A biotype is also known as the sweet potato whitefly, and the B biotype is also known as the silverleaf whitefly (Jones 2003). T. vaporariorum is present in all temperate areas worldwide, whereas $T$. abutilonea has only been described in Cuba and the United States. B. tabaci was originally described in tropical and subtropical regions but it has spread to temperate regions as well. The B biotype is considered highly invasive and, with worldwide spread, has been shown to be the most efficient vector for ToCV transmission (Wintermantel and Wisler 2006).

Both TICV and ToCV induce practically indistinguishable yellowing disease in tomato, which includes interveinal yellowing and thickening of mature leaves, while the new growth at the plant apex appears normal. Disease symptoms usually appear 3 to 4 weeks following inoculation and are readily mistaken for nutritional disorders or pesticide phytotoxicity. Although TICV and $\mathrm{ToCV}$ do not induce any symptoms on tomato fruit, fruit of infected plants are smaller and decreased in number, the ripening process is impeded, and the plants seems to go through early senescence. All of which results in yield and economical losses (Wintermantel 2004; Dalmon et al. 2009).

Although both TICV and ToCV have a wide host range, only TICV infects lettuce. Whereas both TICV and ToCV induce very similar disease symptoms in tomato plants, they can be discriminated using the indicator plants $N$. benthamiana and $N$. clevelandii (Wisler et al. 1998b). Symptoms of both viruses can be confused with nutritional disorders or poor growing conditions; therefore, it has been speculated that the virus might have been present in tomato crops long before being identified (Rojas and Gilbertson 2008). Moreover, both viruses are phloem limited and infected plants carry low viral titers, which complicates accurate diagnostics.

Over the last decade, Crinivirus spp. were reported to infect field and greenhouse tomato crops in Cuba, Turkey, Cyprus, Portugal, Spain, Italy, Israel, Jordan, La Réunion Island, Morocco, Greece, Puerto Rico, and Taiwan (British Society for Plant Pathology website; Louro et al. 2000; Navas-Castillo et al. 2000; Accotto et al. 2001; Wintermantel et al. 2001; Dovas et al. 2002; Varia et al. 2002; Segev et al. 2004; Tsai et al. 2004; Anfoka and Abhary 2007; Martinez-Zubiaur et al. 2008). Interestingly, ToCV was identified in Israel in 2004 while, in 2007, TICV was identified in tomato fields in the Jordan Valley in Jordan (Segev et al. 2004; Anfoka and Abhary 2007). Although the distance between the tomato fields in Jordan and Israel is only a few kilometers, ToCV has not yet been detected in Jordan and TICV has not yet been detected in Israel. This may be linked to different agricultural practices affecting whitefly populations, with most tomato crops in Jordan grown in open fields whereas, in Israel, the majority of the tomato plants are grown in greenhouses.

In addition to whitefly emergence, thrips populations also have notably increased over the last decades, thus facilitating the emergence of thrips-transmitted viruses (Prins and Goldbach 1998). More specifically, the proliferation of thrips-vectored

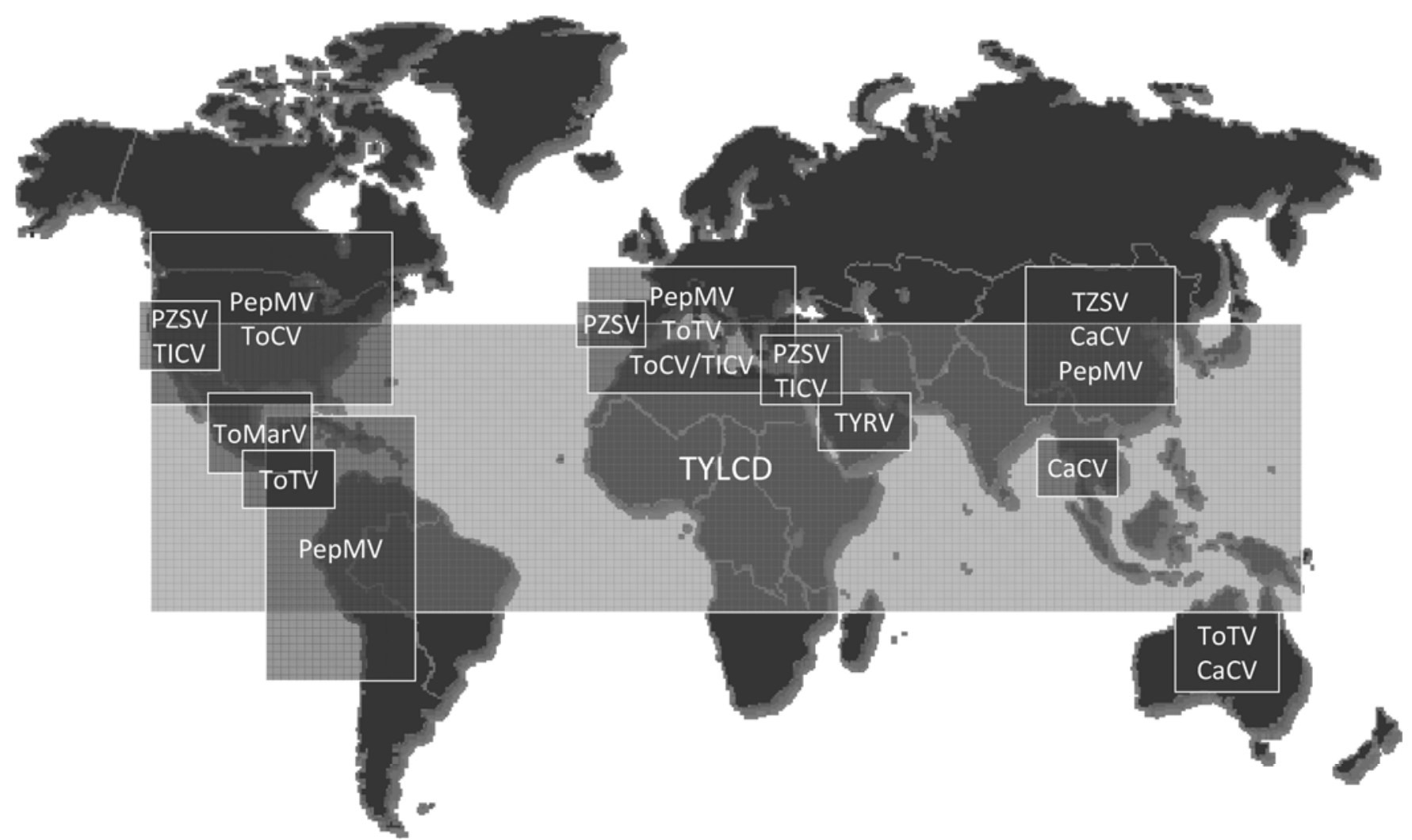

Fig. 2. Geographic distribution of the emerging viruses in tomato crops reviewed in this article. 
Tospovirus spp. has been associated with increasing thrips populations, mainly attributed to the rapid expansion of the western flower thrips (Frankliniella occidentalis) combined with increasing insecticide resistance in thrips populations (Prins and Goldbach 1998; Rojas and Gilbertson 2008). Over recent years, several new species from the genus Tospovirus, infecting tomato crops in Australia, Asia, and the Middle-East, have been reported (Hassani-Mehraban et al. 2005; Knierim et al. 2006; Dong et al. 2008). Tospovirus spp. are enveloped viruses with a tripartite ssRNA genome that belong to the family Bunyaviridae and that cause significant losses in tomato, pepper, and other crops worldwide. Presence of Tospovirus spp. and, more specifically, of TSWV (the Tospovirus type species) and members of the Watermelon silver mottle virus (WSMoV) serogroup, has been documented in Asian tomato production since the mid-1980s. Since then, an increasing number of Tospovirus spp. has been found in different crops all over Asia (Whitfield et al. 2005; Dong et al. 2008). In 1998, a Tospovirus-like disease was reported in tomato crops with necrotic lesions on the foliage and chlorotic ring spots on the fruit in Iran (Hassani-Mehraban et al. 2005). Serological and molecular characterization revealed that this Tospovirus isolate represents a new species, which was tentatively named "Tomato yellow ring virus" (Table 1).

In 2002, a new Tospovirus sp. infecting pepper and tomato in Queensland (Australia) was characterized and tentatively named "Capsicum chlorosis virus" (CaCV) (McMicheal at al. 2002) (Table 1), which was later reported to infect tomato plants in Thailand (Knierim et al. 2006). The virus has also been reported to occur in Taiwan and China (Dong et al. 2008).

In 2005, a devastating new disease was observed in tomato and chili pepper crops in Yunnan, China. Based on electron microscopy, serological studies, and complete nucleotide sequences of the three RNA fragments, it was concluded that the virus represents a new Tospovirus sp., and the name "Tomato zonate spot virus" (TZSV) was proposed (Dong et al. 2008) (Table 1). Phylogenetic analyses show that TZSV clusters in an Asian group of Tospovirus spp., comprising Calla lily chlorotic spot virus (Taiwan), WSMoV (Taiwan and Japan), $\mathrm{CaCV}$ (Taiwan, Australia, Thailand and China), Watermelon bud necrosis virus (India and Southeast Asia), and Melon yellow spot virus (Japan and Taiwan). All these Tospovirus spp. seem to originate from and are presently restricted to Asia (Fig. 2), suggesting that they share a common origin. The high incidence of new Tospovirus spp. in tropical Asian regions suggests a "hot spot" of viral genetic diversity in reservoir host variants from where they are transmitted to commercial crops through increasing vector populations (Rojas and Gilbertson 2008).

In addition to new Tospovirus spp., another unknown, putatively thrips-transmitted virus recently has been reported in open field tomato crops in the Central Valley of California (Batuman et al. 2009). Necrotic symptoms were observed on tomato leaves, stems, and petioles (Fig. 1G), most similar to those induced by Tobacco streak virus (TSV). Although numerous fields were affected, disease incidence in the field was rather low (5 to 20\%). The causal agent was identified as an Ilarvirus sp. (Bromoviridae) with three RNA fragments, and nucleotide sequence analyses revealed 81 to $84 \%$ and 64 to $80 \%$ identity for the three RNAs of Parietaria mottle virus and TSV Ilarvirus spp., respectively. The mode of transmission has not clearly been demonstrated but may involve thrips feeding on infected pollen, as was previously shown for TSV (Sdoodee and Taekle 1987). It was proposed that this virus is representative of a new Ilarvirus sp., tentatively named "Tomato necrotic spot virus" (Batuman et al. 2009) (Table 1).

\section{KNOWN VIRAL PATHOGENS THAT EMERGED IN TOMATO}

PepMV, a Potexvirus sp. that was initially isolated from pepino (S. muricatum) in 1974 in Peru (Jones et al. 1980), was observed for the first time in tomato crops only a decade ago (van der Vlugt 2000) (Table 1). In only a few years' time, the virus became a major disease of glasshouse tomato crops worldwide (French et al. 2001, Mumford and Metcalfe 2001, Cotillon et al. 2002, Aguilar et al. 2002; Maroon-Lango et al. 2005; Ling 2006, Pagán et al. 2006) (Fig. 2). Potexvirus spp. are mechanically transmitted viruses with flexuous, rodshaped particles and an ssRNA genome containing five ORF. PepMV isolates originating from tomato crops in Europe between 2000 and 2003 shared over 99\% nucleotide sequence identity among each other but were clearly distinct $(96 \%$ nucleotide sequence identity) from the original pepino isolate (Verhoeven et al. 2003). In addition, whereas the original pepino isolate was asymptomatic in tomato, the tomato isolates caused a wide variety of symptoms on fruit and vegetative plant parts (van der Vlugt et al. 2000, French et al. 2001, Mumford and Metcalfe 2001, Cotillon et al. 2002, Aguilar et al. 2002). Thus, these isolates were considered to be distinct from the original pepino-infecting strain and were subsequently designated the "European tomato strain" of PepMV (Mumford and Metcalfe 2001; Pagán et al. 2006; Verhoeven et al. 2003). Since 2005 , new genotypes sharing only $80 \%$ nucleotide sequence identity with the European tomato strain have been identified, originating from tomato crops in the United States (US1 and US2) (Maroon-Lango et al. 2005) and from tomato seed from Chile (CH1 and CH2) (Ling 2006). Because nucleotide sequence comparisons suggest that US2 is a recombinant of US1 and $\mathrm{CH} 2$, it was recently proposed to distinguish four PepMV genotypes: the original Peruvian genotype (LP), the European (tomato) genotype (EU), the American genotype US1, and the Chilean genotype $\mathrm{CH} 2$ (Hanssen et al. 2010b). After the initial dominance of the EU genotype in European tomato production, a population shift toward the $\mathrm{CH} 2$ genotype has been reported in several European countries (Gómez et al 2009; Hanssen et al. 2008) whereas, in the United States and Canada, the EU genotype remains dominant (French et al. 2008; Ling et al. 2008). Mixed infections of both genotypes are common and have been suggested to contribute to PepMV population dynamics (Gómez et al. 2009). In addition, recombinants of both genotypes have been reported (Pagán et al. 2006; Hanssen et al. 2008). Recently, the LP genotype has been reported in Belgian tomato production, probably associated with the use of an isolate from this genotype for cross protection as a PepMV control strategy in the Netherlands (Hanssen et al. 2010a). In addition, the US1 genotype was recently isolated in the Canary Islands from greenhouse tomato crops displaying leaf blistering and mosaic (Alfaro-Fernández et al. 2008a).

The typical fruit marbling (Fig. 1C) is generally considered to be the most important PepMV symptom because it significantly impacts the economic value of the crop (Mumford and Metcalfe 2001; Jones and Lammers 2005; Spence et al. 2006; Hanssen et al. 2008). In addition, uneven or blotchy ripening of tomato fruit and the occurrence of open fruit has been associated with PepMV infection (Roggero et al. 2001; Spence et al. 2006; Hanssen et al. 2009b). Symptoms on the vegetative plant parts include yellow angular spots on the leaves, the socalled "nettleheads" (upper young leaves that are distorted, serrated, and upright, with a reduced leaf surface), leaf mosaics, leaf scorching, and leaf blistering or bubbling.

The economic impact of PepMV on the tomato industry varies for different tomato-producing areas, because it depends on 
the structure of the tomato market and, more specifically, on the local marketability of lower-quality fruit (Jones and Lammers 2005; Spence et al. 2006). In addition, large differences in symptom severity and damage have been observed between subsequent cropping seasons and between different geographic areas, suggesting an impact of climate conditions on symptom display (Jordá et al. 2001; Spence et al. 2006). Greenhouse trials conducted in the United Kingdom from 2001 to 2003 revealed considerable differences in damage between subsequent years, with the percentage of downgraded tomato fruit due to PepMV-induced quality loss ranging from 6 to 38\% (Spence et al. 2006). In a questionnaire conducted among Belgian tomato growers, yield losses caused by PepMV were estimated to be negligible while losses due to fruit marbling were estimated around 5\% in the 2005 growth season. By contrast, in 2006, quality losses were less pronounced but the overall yield loss was estimated between 5 and 10\% (Hanssen et al. 2009a). However, large differences were noted between individual growers.

The impact of environmental growth conditions and tomato genotype on PepMV symptom development is not yet fully understood. Similarly, the role of viral genotypes and isolates in differential symptomatology has not yet been completely elucidated. In population studies conducted in Spanish and Belgian tomato production, no correlation between PepMV genotypes and symptomatology were found (Pagán et al. 2006; Hanssen et al. 2008). However, tomato crops that were simultaneously infected with the $\mathrm{CH} 2$ and EU genotype showed significantly enhanced symptom display when compared with crops infected with a single isolate (Hanssen et al. 2008, 2010a). Nevertheless, more and more evidence is accumulating on the importance of the viral isolate in PepMV symptomatology. Studies of Polish and Belgian PepMV isolates revealed clear differences in host range and symptomatology of different $\mathrm{CH} 2$ isolates sharing over $99 \%$ nucleotide sequence identity (Pospieszny et al. 2008; Hasiów-Jaroszewska et al. 2009; Hanssen et al. 2009b).

It is presently unclear what triggered the sudden emergence of PepMV in tomato, although long-distance spread through infected seed has been suggested (Rojas and Gilbertson 2008). Given the high infectivity and persistence of the virus, the recently evidenced, very low seed transmission rate of $0.026 \%$ for seed that were cleaned to industry standards without disinfection may have impacted PepMV epidemiology, especially in the first years after the virus emerged in tomato crops, when control measures had not yet been established (Hanssen et al. $2010 b)$. In addition, increasing global trade of tomato fruit and maybe also cuttings of ornamental pepino cultivars may have contributed to PepMV emergence. For a more detailed overview on PepMV emergence and population dynamics, the reader is referred to a recent review (Hanssen and Thomma 2010).

\section{KNOWN TOMATO VIRUSES WITH A RAPIDLY INCREASING INCIDENCE}

The worldwide emergence of whiteflies, especially of the $B$. tabaci $\mathrm{B}$ biotype, has contributed significantly to the rapid and successful emergence of the tomato yellow leaf curl disease (TYLCD), caused by a complex of viral species and constituting a serious threat to tomato production in many tropical and subtropical regions worldwide (Table 1; Fig. 2). The causal agents are members of the genus Begomovirus within the family Geminiviridae, plant viruses with a circular ssDNA genome. Begomovirus spp. are transmitted by the whitefly B. tabaci in a persistent and circulative manner, and their genome generally consists of two DNA molecules. However, nearly all Begomovirus spp. that cause TYLCD have only one genomic com- ponent. Many different species have been described within this group, most of which have been given the name TYLCV, or derivatives thereof. TYLCD symptoms comprise upward curling of leaflet margins, reduction of leaf surface, yellowing of young leaves, severe stunting, and flower abortion (Moriones and Navas-Castillo 2000) (Fig. 1B). A disease with symptoms similar to TYLCD was already reported in tomato crops in Israel in the late 1930s but the virus was first identified in 1961, and tomato production in the Middle East has been severely affected from the 1970s onward (Cohen and Antignus 1994; Czosnek and Laterrot 1997; Cohen and Lapidot 2007). However, due to a worldwide spread of the B biotype of the vector $B$. tabaci, which has a wider host range than other biotypes and is highly invasive, new TYLCV-like viruses emerged from weed and endemic plant reservoirs in the late 1980s. In addition, with the rapid emergence of whiteflies into new geographic regions, Begomovirus infections have been reported in new tomato production areas over the last decade. The disease was described in Japan, Mexico, and the United States in the late 1990s (Polston et al. 1994; Polston and Anderson 1997; Kato et al. 1998; Ascencio-Ibáñez et al. 1999).

TYLCV hosts that can serve as virus reservoirs might have a large effect on viral emergence in new tomato production regions. Although TYLCV can produce severe symptoms in tomato, it is also able to establish symptomless infections in both wild and cultivated species. For instance, in many tomatogrowing areas, pepper is grown in close proximity. Because pepper was known as a nonhost of TYLCV, whitefly management was not practiced rigorously in pepper plots (Polston and Lapidot 2007). After former, conflicting reports regarding the susceptibility of peppers to TYLCV (Mansour and Al-Musa 1992]; Reina et al. 1999), it was recently demonstrated that some, albeit not all, cultivars of pepper are, in fact, symptomless hosts of TYLCV (Morilla et al. 2005; Polston et al. 2006). Moreover, despite the lack of TYLCV-induced disease symptoms, whiteflies were able to acquire TYLCV from infected pepper plants and transmit the virus to tomato (Polston et al. 2006). Hence, symptomless infected pepper plants can serve as a virus reservoir for the acquisition and transmission of TYLCV. Other asymptomatic hosts of TYLCV may act as reservoirs in a similar manner.

Remarkably, in 2007, a TYLCV outbreak outside the climatic zone in which $B$. tabaci thrives was reported. TYLCV infection was reported in 19 neighboring greenhouse tomato crops in The Netherlands but the virus has been successfully eradicated and no new outbreaks have been reported since then (Botermans et al. 2009). The source of infection could not be identified but nucleotide sequence analyses revealed a high similarity between isolates from the different crops (>99\% identity to the Spanish TYLCV-Alm strain) and, therefore, infection was thought to be initiated from the same source, whereas local spread most likely occurred through $B$. tabaci vectoring (Botermans et al. 2009). Begomovirus spp. emergence in tomato crops has been extensively discussed in several recent reviews (Moriones and Navas-Castillo 2000; Varma and Malathi 2003; Seal et al. 2006; Rojas and Gilbertson 2008); therefore, this topic is not further addressed in this manuscript.

Pelargonium zonate spot virus (PZSV) was first isolated from Pelargonium zonale (Quacquarelli and Gallitelli 1979) and subsequently from tomato crops in Italy. PZSV-infected tomato displayed concentric chlorotic or necrotic rings and line patterns on leaves, stems, and fruit (Gallitelli 1982), and has been the causal agent of multiple disease outbreaks in commercial tomato crops in various geographic regions. PZSV was detected in the late 1990s in greenhouse tomato crops and weeds growing in the immediate vicinity in Spain (Luis-Arteaga 
and Cambra 2000) and, in 2000, in greenhouse-grown tomato plants in southeastern France (Gebre-Selassie et al. 2002). More recently, the virus was isolated from open field tomato in California (Liu and Sears 2007) and Israel (Lapidot et al. 2009) Fig. 2). It was reported that the virus is seedborne in the weed species Diplotaxis erucoides and transmitted to tomato in association with pollen grains carried by thrips, as was previously described for Ilarvirus spp. (Finetti-Sialer and Gallitelli 2003). Also, particle morphology and a number of physiochemical properties are shared with Ilarvirus spp. Because the genome comprises three ssRNA species with an organization that is similar to viral species of the family Bromoviridae, it was suggested that PZSV represents a new genus within this family (Finetti-Sialer and Gallitelli 2003), for which the name "Anulavirus" was proposed (Gallitelli et al. 2005). The virus is seedborne in several hosts and is efficiently transmitted mechanically (Gallitelli 1982; Lapidot et al. submitted).

\section{REEMERGING OLD VIRUSES}

In recent years, the tomato market in Europe has evolved toward a specialized, marketing-driven industry. So-called "specialty" cultivars with varying colors (brown or pink), sizes or shapes (cherry, plum, or beef), tastes (sweet or rather salty), and health-promoting properties (high lycopene content) are gaining importance (e.g., Flandria specialty street). Interestingly, part of this evolution is the reintroduction of "old" tomato cultivars such as Coeur-de-Boeuf onto the market. Especially in France, old tomato cultivars are gaining popularity because of their atypical appearance and flavor (e.g., "Saveurs Anciennes"). Remarkably, these market-driven changes have consequences for plant disease management because these old cultivars usually lack the resistance genes that are commonly exploited in more recently developed commercial tomato cultivars. As a consequence, Tobacco mosaic virus (TMV) and Tomato mosaic virus (ToMV), two Tobamovirus spp. that caused serious losses in tomato production worldwide before resistant cultivars were introduced, are reemerging in tomato production areas where these "old" cultivars are grown. Grower organizations are considering reintroduction of the cross-protection strategy that was frequently used in the 1970s, consisting of the inoculation of young tomato plants with the mild TMV isolate MII-16 (Rast 1972), to protect crops from infection with more aggressive TMV or ToMV variants. However, complications can occur when TMV infects a susceptible cultivar that is grafted onto a TMV-resistant rootstock. Because TMV resistance is generally conferred by the $\mathrm{Tm} 2^{2}$ resistance gene (Pelham 1966) and based on a hypersensitive response (HR), infection of the susceptible scion will result in necrosis at the grafting point and subsequent plant collapse and death. In addition, the high TMV infection pressure in areas where both susceptible and resistant cultivars are grown results in a higher incidence of leaf and stem necrosis in resistant cultivars due to the activation of the HR upon challenge with TMV. Finally, because these established viruses might occur in mixed infections with currently emerging viruses such as PepMV or ToTV, there may be a risk of synergism, or even recombination events, which might lead to new viral disease problems in the future.

\section{CONTROL STRATEGIES}

Over the past 20 years, several viruses have emerged in tomato production worldwide, some of which pose a considerable threat to greenhouse and open-field tomato production. In particular, the devastating Begomovirus spp. and the highly contagious PepMV are currently hampering the economic profitability of tomato production worldwide. Optimal control strategies are virus specific and depend on the incidence, transmission, and availability of resistant cultivars. Within the European Union, control strategies for plant virus emergence depend on pest risk analyses and the phytosanitary measures that are taken, which can include a quarantine status on seed, seedlings, or commercial crops. Begomovirus spp. and the Crinivirus spp. TICV and ToCV are listed in the EPPO A2 alert list. TYLCV and related species were assigned a quarantine status for tomato in EU member states (EU directive 2000/ 29/EC), while PepMV (Commission Decision 2001/536/EC and 2004/200/EC) currently has a quarantine status only on tomato seed.

Control of whitefly-transmitted viruses depends mainly on the availability of efficient insecticides, insect-proof greenhouses, and resistant cultivars (Polston and Lapidot 2007). Tomato cultivars with resistance to TYLCV, ToTV, and ToMarV are commercially available. Genes controlling resistance to TYLCV and other tomato-infecting Begomovirus spp. (Ty genes) were introgressed from several wild Solanum species. The intermediate TYLCV resistance gene $T y 1$, introgressed from S. chilense LA1969 (Michelson et al. 1994; Zamir et al. 1994), is the most commonly used source of TYLCV resistance, while information on ToTV resistance has not been published. A recent $F_{1}$ diallele study (Vidavski et al. 2008) demonstrated that several of these $T y$ resistance genes may interact with each other and, in some cases, result in hybrid plants displaying higher TYLCV resistance compared with their parental lines. This suggests that pyramiding resistance genes originating from different resistance sources can be effective in obtaining cultivars that are highly resistant to Begomovirus spp. (Vidavski et al. 2008).

In contrast, cultivars with resistance to Crinivirus spp. are not yet available. The Tospovirus TSWV-resistance gene sw5 (Stevens 1964) is widely used in commercial cultivars but resistance for the newly described Tospovirus spp. is not yet available in commercial tomato cultivars. Resistance strategies for Tospovirus spp. control are compromised by the continuous emergence of resistance-breaking strains and new species (Pappu et al. 2009). Control of Tospovirus spp. is also hampered by the rapid development of insecticide resistance within thrips populations. Alternatives to chemical thrips control comprise the use of thrips predators or thrips-proof insect nets (Jones 2004), although the small mesh size required for thripsproof nets leads to reduced ventilation and, thus, to suboptimal climate conditions in the greenhouse. A promising future disease management strategy for whitefly- and thrips-transmitted viruses could consist of genetic resistance to the insect vectors rather than to the viruses they transmit.

For the highly contagious, mechanically transmitted PepMV and PZSV, control depends largely on hygienic measures, because resistant cultivars are not yet available. In addition, cross-protection strategies might be developed in production areas with a high infection pressure, provided that only one virus is dominant and that the viral population is homogenous (Lecoq 1998; Gal-On and Shiboleth 2006).

Future control strategies for plant virus diseases may include transgenic resistance. In particular, the introduction of an inverted repeat transgene, that is derived from viral sequences and, thus, is able to trigger gene silencing of the viral gene expression, into the plant genome is a promising strategy (Prins et al. 2008).

\section{CONCLUDING REMARKS}

Viral diseases are an important limiting factor in many crop production systems. Owing to their large population size and 
short generation time, viruses have a great potential to quickly evolve and adapt under natural selection pressure. Surprisingly, however, resistance to plant viruses is generally more durable than resistance to cellular pathogens such as fungi and bacteria (Harrison 1981; García-Arenal and McDonald 2003). The size of the effective viral population (the part of the population that passes its genes onto the next generation), which is generally several orders of magnitude smaller than the census population size (the total population), and the strong selection pressure acting on viral ORF that often overlap and generally encode multifunctional proteins, seem to play an important role in restricting the evolutionary potential of plant viruses (García-Arenal and McDonald 2003). Nevertheless, emergence of new viral species and genotypes is frequently reported, probably driven by changes in climate, cultural practices, host plants, and virus vectors, in addition to changes in the viral genome. Tomato is by far the most important vegetable crop, and many viral species that infect tomato crops have been described. Over recent years, several viral diseases have emerged in greenhouse tomato crops and are presently impacting freshmarket tomato production in diverse geographic areas worldwide. These are i) new viral species, ii) known viral pathogens of other crops that are emerging in tomato, iii) tomato viruses with a rapidly increasing incidence, and iv) old viruses that reemerge due to the cultivation of old cultivars that lack the resistance genes that are commonly exploited in more recently developed commercial tomato cultivars. Optimal strategies to reduce the impact of emerging viruses on current and future tomato production systems will most probably consist of an integrated pest management approach, in which the most efficient control measures are combined depending on the biology of the virus and its vector (Jones 2004). Consequently, good insight into the biology and epidemiology of these viruses is critical for the development of suitable control strategies.

\section{ACKNOWLEDGMENTS}

I. M. Hanssen is supported by IWT Vlaanderen (IWT 60669; Brussels). B. P. H. J. Thomma is supported by a Vidi grant of the Research Council for Earth and Life sciences (ALW) of the Netherlands Organization for Scientific Research (NWO). We thank P. Maris (De Ruiter Seeds) and G. Bonnet (Syngenta Seeds) for critically reading the manuscript and for providing information on the current tomato market.

\section{LITERATURE CITED}

Accotto, G. P., Varia, A. M., Vecchiati, M., Finetti-Sialer, M. M., Gallitelli, D., and Davino, M. 2001. First report of Tomato chlorosis virus in Italy. Plant Dis. 85:1208.

Aguilar, J. M., Hernandez-Gallardo, M. D., Cenis, J. L., Lacasa, A., and Aranda, M. A. 2002. Complete sequence of the Pepino mosaic virus RNA genome. Arch. Virol. 147:2009-2015.

Alfaro-Fernández, A., Córdoba-Sellés, C., Cebrián, M. C., SánchezNavarro, J. A., Espino, A., Martín, R., and Jordá, C. 2007a. First report of Tomato torrado virus in tomato in the Canary Islands, Spain. Plant Dis. 91:1060.

Alfaro-Fernández, A., Córdoba-Sellés, C., Cebrián-Micó, M. C., Font, M., Juárez, V., Median, A., Lacasa, A., Sánchez-Navarro, J. A., Pallas, V., and Jordá-Gutiérrez, C. 2007b. Advances in the study of tomato "Torrao" or "Cribado" syndrome. Bol. San. Veg. Plagas 33:99-109.

Alfaro-Fernández, A., Córdoba-Sellés, C., Cebrián, M. C., HerreraVásquez, J. A., and Jordá, C. 2008a. First report of the US1 strain of Pepino mosaic virus in tomato in the Canary Islands, Spain. Plant Dis. 92:11.

Alfaro-Fernández, A., Córdoba-Sellés, C., Cebrián, M. C., HerreraVásquez, J. A., Sánchez-Navarro, J. A., Juárez, M., Espino, A., Martín, R., and Jordá, C. 2008b. First report of Tomato torrado virus on weed hosts in Spain. Plant Dis. 92:831.

Alfaro-Fernández, A., Bese, G., Córdoba-Sellés, C., Cebrián, M. C., Herrera-Vásquez, J. A., Forray, A., and Jordá C, 2009. First report of Tomato torrado virus infecting tomato in Hungary. Plant Dis. 93:554.

Amari, K., Gonzalez-Ibeas, D., Gómez, P., Sempere, R. N., Sanchez-Pina,
M. A., Aranda, M. A., Diaz-Pendon, J. A., Navas-Castillo, J., Moriones, E., Blanca, J., Hernandez-Gallardo, M. D., and Anastasio, G. 2008. Tomato torrado virus is transmitted by Bemisia tabaci and infects pepper and eggplant in addition to tomato. Plant Dis. 92:1139.

Anfoka, G. H., and Abhary, M. K. 2007. Occurrence of Tomato infectious chlorosis virus (TICV) in Jordan. EPPO Bull. 37:186-190.

Ascencio-Ibáñez, J. T., Díaz-Plaza, R., Méndez-Lozano, J., MonsalveFonnegra, Z. I., Argüella-Astroga, G. R., and Rivera-Bustamante, R. F 1999. First report of Tomato yellow leaf curl Geminivirus in Yucatán, Mexico. Plant Dis. 83:1178.

Batuman, O., Miyao, G., Kuo, Y.-W., Chen, L.-F., Davis, R. M., and Gilbertson, R. L. 2009. An outbreak of a necrosis disease of tomato in California in 2008 was caused by a new Ilarvirus species related to $\mathrm{Pa}$ rietaria mottle virus. Plant Dis. 93:546.

Botermans, M., Verhoeven, J. T. .J., Jansen, C. C. C., Roenhorst, J. W., Stijger, C. M. M., and Pham, K. T. K. 2009. First report of Tomato yellow leaf curl virus in tomato in the Netherlands. Plant Dis. 93:1073.

Brunt, A. A., Crabtree, K., Dallwitz, M. J, Gibbs, A. J., Watson, L., Zurcher, E. J., eds. 1996. Plant Viruses Online: Descriptions and Lists from the VIDE Database. Version: 20th August 1996. www.agls.uidaho.edu/ebi/vdie/refs.htm. Published online

Cohen, S., and Harpaz, I. 1964. Periodic rather than continual acquisition of a new tomato virus by its vector, the tobacco whitefly (Bemisia tabaci Gennadius). Entomol. Exp. Appl. 7:155-166.

Cohen, S., and Antignus, Y. 1994. Tomato yellow leaf curl virus (TYLCV), a whitefly-borne Geminivirus of tomatoes. Adv. Dis. Vector Res. 10:259-288.

Cohen, S., and Lapidot, M. 2007. Appearance and expansion of TYLCV: A historical point of view. Pages 3-12 in: Tomato Yellow Leaf Curl Virus Disease. H. Czosnek, ed. Springer, Dordrecht, The Netherlands.

Cotillon, A. C., Girard, M., and Ducouret, S. 2002. Complete nucleotide sequence of the genomic RNA of a French isolate of Pepino mosaic virus (PepMV). Arch. Virol. 147:2231-2238.

Czosnek, H., and Laterrot, H. 1997. A world-wide survey of tomato yellow leaf curl viruses. Arch. Virol. 142:1391-1406.

Dalmon, A., Fabre, F., Guilbaud, L., Lecoq, H., and Jacquemond, M. 2009. Comparative whitefly transmission of Tomato chlorosis virus and Tomato infectious chlorosis virus from single or mixed infections. Plant Pathol. 28:221-227.

Domingo, E. 2000. Viruses at the edge of adaptation. Virology 270:251253

Dong, J.-H., Cheng, X.-F., Yin, Y.-Y., Fang, Q., Ding, M., Li T.-T., Zhang, L.-Z., Su, X.-X., McBeath, J. H., and Zhang, Z.-K. 2008. Characterization of tomato zonate spot virus, a new Tospovirus in China. Arch. Virol. 153:855-864.

Dovas, C. I., Katis, N. I., and Avgelis, A. D. 2002. Multiplex detection of criniviruses associated with epidemics of a yellowing disease of tomato in Greece. Plant Dis. 86:1345-1349.

Duffus, J. E., Liu, H.-Y., and Wisler, G. C. 1996. Tomato infectious chlorosis virus - a new clostero-like virus transmitted by Trialeurodes vaporariorum. Eur. J. Plant Pathol. 102:219-226.

EPPO. 2009. First record of Tomato torrado virus in Australia. EPPO Reporting Service No. 2. http://archives.eppo.org/EPPOReporting/2009/ Rse-0902. pdf.

Finetti-Sialer M., and Gallitelli, D. 2003. Complete nucleotide sequence of Pelargonium zonate spot virus and its relationship with the family Bromoviridae. J. Gen. Virol. 84:3143-3151.

French, C. J., Bouthillier, M., Bernardy, M., Ferguson, G., Sabourin, M. Johnson, R. C., Masters, C., Godkin, S., and Mumford, R. 2001. First report of Pepino mosaic virus in Canada and the United States. Plant Dis. 85:1121.

French, C. J., Bunckle, A., Ferguson, G., Dubeau, C., Bouthillier, M., and Bernardy, M. G. 2008. Pepino mosaic virus in Canada; phylogeny of complete sequences and effects of virus infection on fruit yield. J. Plant Pathol. 90 (Suppl.):S2.198.

Gallitelli, D. 1982. Properties of tomato isolate of Pelargonium zonate spot virus. Ann. Appl. Biol. 100:457-466.

Gallitelli, D., Finetti-Sialer, M., and Martelli, G. P. 2005. Anulavirus, a proposed new genus of plant viruses in the family Bromoviridae. Arch. Virol. 150:407-411.

Gal-On, A., and Shiboleth, Y. M. 2006. Cross protection. Pages 261-268 in: Natural Resistance Mechanisms of Plants to Viruses. G. Loebenstein and J. P. Carr, eds. Kluwer Academic Publishers, Dordrecht, The Netherlands.

García-Arenal, F., and McDonald, B. A. 2003. An analysis of the durability of resistance to plant viruses. Phytopathology 93:941-952.

Gebre-Selassie, K., Delecolle, B., Gognalons, P., Dufour, O., Gros, C., Cotillon, A.C., Parrella, G., and Marchoux, G. 2002. First report of an isolate of Pelargonium zonate spot virus in commercial glasshouse tomato crops in southeastern France. Plant Dis. 86:1052. 
Gómez, P., Sempere, R. N., Elena, S. F., and Aranda, M. A. 2009. Mixed infections of Pepino mosaic virus strains modulate the evolutionary dynamics of this emergent virus. J. Virol. DOI:10.1128/JVM.01486-09.

Hassani-Mehraban, A., Saaijer, J., Peters, D., Goldbach, R., and Kormelink, R. 2005. A new tomato-infecting Tospovirus from Iran. Phytopathology 95:852-858.

Hanssen, I. M., and Thomma, B. P. H. J., 2010. Pepino mosaic virus: A successful pathogen that rapidly evolved from emerging to endemic in tomato crops. Mol. Plant Pathol. 11:179-189.

Hanssen, I. M., Paeleman, A., Wittemans, L., Goen, K., Lievens, B., Bragard, C., Vanachter, A. C. R. C., and Thomma, B. P. H. J. 2008. Genetic characterization of Pepino mosaic virus isolates from Belgian greenhouse tomatoes reveals genetic recombination. Eur. J. Plant Pathol. 121:131-46.

Hanssen, I. M., Paeleman, A., Van Bergen, L., Vandewoestijne, E. Wittemans, L., Goen, K., Vanachter, A. C. R. C., and Thomma, B. P. H. J. 2009a. Survey of symptom expression and damage caused by Pepino mosaic virus (PepMV) in commercial tomato production in Belgium. Acta Hortic. 808:185-92.

Hanssen, I. M., Paeleman, A., Vandewoestijne, E., Van Bergen, L., Bragard, C., Lievens, B., Vanachter, A. C. R. C., and Thomma, B. P. H. J. 2009b. Pepino mosaic virus isolates and differential symptomatology in tomato. Plant Pathol. 58:450-460.

Hanssen, I. M., Gutiérrez-Aguirre, I., Paeleman, A., Goen, K., Wittemans, L., Lievens, B., Vanachter, A. C. R. C., Ravnikar, M., and Thomma, B. P. H. J. 2010a. Cross-protection or enhanced symptom display in greenhouse tomato co-infected with different Pepino mosaic virus isolates. Plant Pathol. 59:13-21.

Hanssen, I. M., Mumford, R., Blystad, D.-R., Cortez, I., Hasiówjareszewska, B., Hristova, D., Pagán, I., Pepeira, A.-M., Peters, J., Pospieszny, H., Ravnikar, M., Stijger, I., Tomassoli, L., Varveri, C., van der Vlugt, R., and Nielsen, S. L. 2010b. Seed transmission of Pepino mosaic virus in tomato. Eur. J. Plant Pathol. 126:145-152.

Harrison, B. D. 1981. Plant virus ecology: Ingredients, interactions and environmental influences. Ann. Appl. Biol. 99:195-209.

Hasiów-Jaroszewska, B., Pospieszny, H., and Borodynko, N. 2009. New necrotic isolates of Pepino mosaic virus representing the $\mathrm{CH} 2$ genotype. J. Phytopathol. 157:494-496.

Herrera-Vasquez, J. A., Alfaro-Fernández, A., Córdoba-Selles, M. C. Cebrian, M. C., Font, M. I., and Jordá, C. 2009. First report of Tomato torrado virus infecting tomato in single and mixed infections with Cucumber mosaic virus in Panama. Plant Dis. 93:198.

Jones, D. R. 2003. Plant viruses transmitted by whiteflies. Eur. J. Plant Pathol. 109:195-219.

Jones, D. R., and Lammers, W. 2005. Pest risk analysis for Pepino mosaic virus. York: Central Science Laboratory. Department for Environment Food and Rural Affairs, London.

Jones, R. A. C. 2004. Using epidemiological information to develop effective integrated virus disease management strategies. Virus Res. 100:5-30.

Jones, R. A. C., Koenig, R., and Lesemann, D. E. 1980. Pepino mosaic virus, a new Potexvirus from pepino (Solanum muricatum). Ann. Appl. Biol. 94:61-68.

Jordá, C., Lázaro-Perez, A., and Martinez-Culebras, P. V. 2001. First report of Pepino mosaic virus on tomato in Spain. Plant Dis. 85:1292.

Kato, K., Onuki, M., Fuji, S., and Hanada, K. 1998. The first occurrence of Tomato yellow leaf curl virus in tomato (Lycopersicon esculentum Mill.) in Japan. Ann. Phytopathol. Soc. Jpn. 64:552-559.

Knierim, D., Blawid, R., and Maiss, E. 2006. The complete nucleotide sequence of a Capsicum chlorosis virus isolate from Lycopersicon esculentum in Thailand. Arch. Virol. 151:1761-1782.

Lapidot, M., Leibman, D., Gelbart, D., Davidovitz, M., Machbash, Z., Cohen, S., and Gal-On, A. 2009. Pelargonium zonate spot virus-a new viral disease of tomato in Israel. Phytoparasitica 37:268-269.

Lapidot, M., Guenoune-Gelbart, D., Leibman, D., Holdengrebe, V., Davidovitz, M., Machbash, Z., Kliemann-Shoval, S., Cohen, S., and Gal-On, A. Pelargonium zonate spot virus is seed and pollen-transmitted in tomato. Submitted.

Lecoq, H. 1998. Control of plant virus diseases by cross protection. Pages 33-40 in: Plant Virus Disease Control. A. Hadidi, R. K. Khetarpal, and H. Koganezawa, eds. American Phytopathological Society Press, St. Paul, MN, U.S.A.

Le Gall, O., Christian, P., Fauquet, C. M., King, A. M. Q., Knowles, N. J., Nakashima, N., Stanway, G., and Gorbalenya, E. E., 2008. Picornavirales, a proposed order of positive-sense single-stranded RNA viruses with a pseudo $\mathrm{T}=3$ virion architecture. Arch. Virol. 153:715-727.

Ling, K. 2006. Molecular characterization of two Pepino mosaic virus variants from imported tomato seed reveals high levels of sequence identity between Chilean and US isolates. Virus Genes 34:1-8.

Ling, K., Wintermantel, W. M., and Bledsoe, M. 2008. Genetic composi- tion of Pepino mosaic virus population in North American greenhouse tomatoes. Plant Dis. 92:1683-1688.

Liu, H., and Sears, J. L. 2007. First report of Pelargonium zonate spot virus from tomato in the United States. Plant Dis. 91:633.

Louro, D., Accotto, G. P., and Vaira, A. M. 2000. Occurrence and diagnosis of Tomato chlorosis virus in Portugal. Eur. J. Plant Pathol. 106:589592.

Luis-Arteaga, M., and Cambra, M. 2000. First report of natural infection of greenhouse-grown tomato and weed species by Pelargonium zonate spot virus in Spain. Plant Dis. 84:807.

Mansour, A., and Al-Musa, A., 1992. Tomato yellow leaf curl virus: Host range and virus-vector relationships. Plant Pathol. 41:122-125.

Maroon-Lango, C. J., Guaragna, M. A., Jordan, R. L., Hammond, J. Bandla, M., and Marquardt, S. K. 2005. Two unique US isolates of Pepino mosaic virus from a limited source of pooled tomato tissue are distinct from a third (EU like) US isolate. Arch. Virol. 150:1187-1201.

Martinez-Zubiaur, Y., Fiallo-Olivé, E., Carrillo-Tripp, J., and RiveraBustamante, R. 2008. First report of Tomato chlorosis virus infecting tomato in single and mixed infections with Tomato yellow leaf curl virus in Cuba. Plant Dis. 92:836.

McMicheal, L. A., Persley, D. M., and Thomas, J. E. 2002. A new Tospovirus serogroup IV species infecting Capsicum and tomato in Queensland, Australia. Australas. Plant Pathol. 31:231-239.

Michelson, I., Zamir, D., and Czosnek, H. 1994. Accumulation and translocation of Tomato yellow leaf curl virus (TYLCV) in a Lycopersicon esculentum breeding line containing the L. chilense TYLCV tolerance gene Ty-1. Phytopathology 84:928-933.

Morilla, G., Janssen, D., García-Andrés, S., Moriones, E., Cuadrado, I. M. and Bejarano, E. R. 2005. Pepper (Capsicum annuum) is a dead-end host for Tomato yellow leaf curl virus. Phytopathology 95:1089-1097.

Moriones, E., and Navas-Castillo, J. 2000. Tomato yellow leaf curl virus, an emerging virus complex causing epidemics worldwide. Virus Res. 71:123-134.

Moya, A., Holmes, E. C., and González-Candelas, F. 2004. The population genetics and evolutionary epidemiology of RNA viruses. Nat. Rev. 2:279-288.

Mumford, R. A., and Metcalfe, E. J. 2001. The partial sequencing of the genomic RNA of a UK isolate of Pepino mosaic virus and the comparison of the coat protein sequence with other isolates from Europe and Peru. Arch. Virol. 146:2455-2460.

Navas-Castillo, J., Camero, R., Bueno, M., and Moriones, E. 2000. Severe yellowing outbreaks in tomato in Spain associated with infections of Tomato chlorosis virus. Plant Dis. 84:835-837.

Pagán, I., Córdoba-Sellés, M. C., Martinez-Priego, L., Fraile, A., Malpica, J. M., Jordá, C., and García-Arenal, F. 2006. Genetic structure of the population of Pepino mosaic virus infecting tomato crops in Spain. Phytopathology 96:274-279.

Pappu, H. R., Jones, R. A. C., and Jain, R. K. 2009. Global status of Tospovirus epidemics in diverse cropping systems: Successes achieved and challenges ahead. Virus Res. 141:219-236.

Pelham, J. 1966. Resistance in tomato to Tobacco mosaic virus. Euphytica 15:258-267.

Polston, J. E., and Anderson, P. K. 1997. The emergence of whitefly-transmitted geminiviruses in tomato in the western hemisphere. Plant Dis. 81:1358-1369.

Polston, J. E., Bois, D., Serra, C.A., and Concepcion, S. 1994. First report of a tomato yellow leaf curl-like Geminivirus in the Western Hemisphere. Plant Dis. 78:831.

Polston, J. E., Cohen, L., Sherwood, T. A., Joseph, R. B., and Lapidot, M. 2006. Capsicum species: Symptomless hosts and reservoirs of Tomato yellow leaf curl virus. Phytopathology 96:447-452.

Polston, J. E., and Lapidot, M. 2007. Management of Tomato yellow leaf curl virus: US and Israel perspectives. Pages 251-262 in: Tomato Yellow Leaf Curl Virus Disease. H. Czosnek, ed. Dordrecht, The Netherlands, Springer.

Pospieszny, H., Borodynko, N., Obrepalska-Steplowska, A., and Hasiow, B. 2007. The first report of Tomato torrado virus in Poland. Plant Dis. 91:1364.

Pospieszny, H., Hasiów, B., and Borodyndo, N. 2008. Characterization of two distinct Polish isolates of Pepino mosaic virus. Eur. J. Plant Pathol. 122:443-445

Prins, M., and Goldbach, R. 1998. The emerging problem of Tospovirus infection and nonconventional methods of control. Trends Microbiol. 6:31-35.

Prins, M., Laimer, M., Noris, E., Schubert, J., Wasseneger, M., and Tepfer M. 2008. Strategies for antiviral resistance in transgenic plants. Mol. Plant Pathol. 9:73-83.

Quacquarelli, A., and Gallitelli, D. 1979. Three viruses of Pelargonium zonale in Apulia. Phytopathol. Mediterr. 18:61-70.

Rast, A. T. B. 1972. MII_16, an artificial symptomless mutant of Tobacco 
mosaic virus for seedling inoculation of tomato crops. Neth. J. Plant Pathol. 78:110-112.

Reina, J., Morilla, G., Bejarano, E. R., Rodríguez, M. D., and Janssen, D. 1999. First report of Capsicum annuum plants infected by Tomato yellow leaf curl virus. Plant Dis. 83:1176.

Roggero, P., Masenga, V., Lenzi, R., Coghe, F., Ena, S., and Winter, S. 2001. First report of Pepino mosaic virus in tomato in Italy. Plant Pathol. 50:798.

Rojas, M. R., and Gilbertson, R. L. 2008. Chapter 3, Emerging plant viruses: A diversity of mechanisms and opportunities. Pages 27-51 in: Plant Virus Evolution. M. J. Roossinck, ed. Springer-Verlag, Berlin, Heidelberg, Germany.

Sanfaçon, H., Wellink, J., Le Gall, O., Karasev, A., van der Vlugt, R., and Wetzel, T. 2009. Secoviridae: A proposed family of plant viruses within the order Picornavirales that combines the families Sequiviridae and Comoviridae, the unassigned genera Cheravirus and Sadwavirus, and the proposed genus Torradovirus. Arch. Virol. 154:899-907.

Sdoodee, R., and Teakle, D. S. 1987. Transmission of Tobacco streak virus by Thrips tabaci: A new method of plant virus transmission. Plant Pathol. 36:377-380.

Seal, S. E., VandenBosch, F., and Jeger, M. J., 2006. Factors influencing Begomovirus evolution and their increasing global significance: Implications for sustainable control. Crit. Rev. Plant Sci. 25:23-46.

Segev, L., Wintermantel, W. M., Polston, J. E., and Lapidot, M. 2004. First report of Tomato chlorosis virus in Israel. Plant Dis. 88:1160.

Spence, N. J., Basham, J., Mumford, R .A., Hayman, G., Edmondson, R., and Jones, D. R. 2006. Effect of Pepino mosaic virus on the yield and quality of glasshouse-grown tomatoes in the UK. Plant Pathol. 55:595606.

Stevens, J. M. 1964. Tomato Breeding. Project Report W-Vv1. Department of Agricultural Technical Services, Republic of South Africa.

Tsai, W. S., Shih, S. L., Green, S. K., Hanson, P., and Liu, H. Y. 2004. First report of the occurrence of Tomato chlorosis virus and Tomato infectious chlorosis virus in Taiwan. Plant Dis. 88:311.

Turina, M., Ricker, M. D., Lenzi, R., Masenga, V., and Ciuffo, M. 2007. A severe disease of tomato in the Culiacan area (Sinaloa, Mexico) is caused by a new picorna-like viral species. Plant Dis. 91:932-941.

van der Vlugt, R. A. A., Stijger, C. C. M. M., Verhoeven, J. T. J., and Lesemann, D. E. 2000. First report of Pepino mosaic virus on tomato. Plant Dis. 84:103.

Varia, A. M., Accotto, G. P., Vecchiati, M., and Bragaloni, M. 2002. Tomato infectious chlorosis virus causes leaf yellowing and reddening of tomato in Italy. Phytoparasitica 30:290-294.

Varma, A., and Malathi, V. G., 2003. Emerging geminivirus problems: A serious threat to crop production. Ann. Appl. Biol. 142:145-164.

Verbeek, M., Dullemans, A. M., van den Heuvel, J. F. J. M., Maris, P. C., and van der Vlugt, R. A. A. 2007. Identification and characterisation of Tomato torrado virus, a new plant picorna-like virus from tomato. Arch. Virol. 152:881-890.
Verbeek, M., Dullemans, A. M., van den Heuvel, J. F. J. M., Maris, P. C., and van der Vlugt, R. A. A. 2008. Tomato marchitez virus, a new plant picorna-like virus from tomato related to Tomato torrado virus. Arch. Virol. 153:127-134.

Verhoeven, J. T. J., van der Vlugt, R., and Roenhorst, J. W. 2003. High similarity between tomato isolates of Pepino mosaic virus suggests a common origin. Eur. J. Plant Pathol. 109:419-425.

Vidavski, F., Czosnek, H., Gazit, S., Levy, D., and Lapidot, M. 2008. Pyramiding of genes conferring resistance to Tomato yellow leaf curl virus from different wild tomato species. Plant Breed. 127:625-631.

Whitfield, A. E., Ullman, D. E., and German, T. L. 2005. Tospovirus-thrips interactions. Annu. Rev. Phytopathol. 43:459-489.

Wintermantel, W. M. 2004. Emergence of greenhouse whitefly (Trialeurodes vaporariorum) transmitted criniviruses as threats to vegetable and fruit production in North America. Published online by The American Phytopathological Society, St. Paul, MN, U.S.A.

Wintermantel, W. M., and Wisler, G. C. 2006. Vector specificity, host range and genetic diversity of Tomato chlorosis virus. Plant Dis. 90:814-819.

Wintermantel, W. M., Polston, J. E., Escudero, J., and Paoli, E. R. 2001. First report of Tomato chlorosis virus in Puerto Rico. Plant Dis. $85: 228$.

Wisler, G. C., Liu, H.-Y., Klaassen, V. A., Duffus, J. E., and Falk, B. W. 1996. Tomato infectious chlorosis virus has a bipartite genome and induces phloem-limited inclusions characteristic of the closteroviruses. Phytopathology 86:622-626.

Wisler, G. C., Duffus, J. E., Liu, H.-Y., and Li, R. H. 1998a. Ecology and epidemiology of whitefly-transmitted closteroviruses. Plant Dis. 82:270-280.

Wisler, G. C., Li, R. H., Liu, H.-Y., Lowry, D. S., and Duffus, J. E. 1998b. Tomato chlorosis virus: A new whitefly-transmitted, phloem-limited bipartite Closterovirus of tomato. Phytopathology 88:402-409.

Zamir, D., Ekstein-Michelson, I., Zakay, Y., Navot, N., Zeidan, M., Sarfatti, M., Eshed, Y., Harel, E., Pleban, T., Oss, H. V., Kedar, N., Rabinowitch, H. D., and Czosnek, H. 1994. Mapping and introgression of a Tomato yellow leaf curl virus tolerance gene, TY-1. Theor. Appl. Genet. 88:141-146.

\section{AUTHOR-RECOMMENDED INTERNET RESOURCES}

British Society for Plant Pathology, new disease report website: www.bspp.org.uk/publications/new-disease-reports/index.php

European and Mediterranean Plant Protection Organization: www.eppo.org/QUARANTINE/quarantine.htm

Flandria specialty street website: www.specialtystreet.be

Savéol website: www.savéol.com

United Nations Food and Agricultural Organization FAOSTAT website: faostat.fao.org/site/339/default.aspx 